\title{
Analisa Daya Dukung Tanah untuk Pondasi Tiang Pancang pada Rencana Pembangunan Komplek Pendidikan Islam Al Azhar 57 Jambi
}

\author{
${ }^{1}$ Danipra Setiyo, ${ }^{2}$ Suhendra, ${ }^{3} \mathrm{M}$. Nuklirullah \\ ${ }^{1}$ Mahasiswa S1 Program Studi Teknik Sipil Fakultas Teknik Universitas Batanghari, Jambi \\ ${ }^{2,3}$ Dosen Program Studi Teknik Sipil Fakultas Teknik Universitas Batanghari, Jambi \\ e-mail: suhendra_domas@yahoo.com
}

\begin{abstract}
Abstrak. Pondasi tiang pancang merupakan salah satu jenis dari pondasi dalam yang umum digunakan, yang berfungsi untuk menyalurkan beban struktur kelapisan tanah keras yang mempunyai kapasitas daya dukung tinggi yang letaknya cukup dalam didalam tanah. Daya dukung pondasi tiang pancang dipengaruhi oleh daya dukung ujung tiang dan daya dukung selimut tiang. Studi analisa daya dukung tanah untuk pondasi tiang pancang dilaksanakan pada proyek pembangunan komplek pendidikan Islam Al Azhar 57 Jambi di kawasan kota baru terpadu Citra Raya City, Mendalo Darat, Kecamatan Jambi Luar Kota, Kabupaten Muaro Jambi, Provinsi Jambi. Tujuan dari studi ini adalah menghitung daya dukung pondasi tiang pancang tunggal dan penurunannya. Metode-metode yang digunakan dalam penelitian ini adalah metode Aoki dan De Alencar dan metode Langsung berdasarkan data hasil uji sondir atau Cone Penetration Test (CPT), metode Meyerhoff berdasarkan data hasil Standar Penetration Test (SPT) dan metode Alpha $(\alpha)$, metode Lambda $(\lambda)$ dan metode Beta $(\beta)$ berdasarkan data hasil uji laboratorium. Perhitungan daya dukung pondasi tiang pancang dari masing-masing metode dibandingkan. Hasil analisis perhitungan daya dukung pondasi tiang pancang pada enam titik sondir yang ditinjau di kedalaman 10 meter menunjukkan bahwa daya dukung tiang tunggal yang terendah pada titik S 06 berdasarkan metode Aoki dan De Alencar adalah $Q_{u}=88,84$ ton dengan $Q_{a}=$ 35,54 ton dan penurunannya $33,08 \mathrm{~mm}$, berdasarkan metode Langsung daya dukung tiang tunggal yang terendah pada titik S 05 yaitu $Q_{u}=365,34$ ton dengan $Q_{a}=84,87$ ton dan penurunannya 44,26 mm, berdasarkan metode Meyerhoff dengan data SPT yang terendah pada titik BH 02 yaitu $Q_{u}=62,70$ ton dengan $Q_{a}=38,96$ ton dan penurunannya 19,11 $\mathrm{mm}$, berdasarkan metode Alpha $(\alpha)$ dengan data hasil uji laboratorium nilai yang terendah pada titik BH 01 yaitu $Q_{u}=$ 83,38 ton dengan $Q_{a}=27,79$ ton dan penurunannya $38,42 \mathrm{~mm}$, berdasarkan metode Lambda $(\lambda)$ nilai daya dukung yang terendah pada titik BH 01 yaitu $Q_{u}=71,10$ ton dengan $Q_{a}=23,70$ ton dan penurunannya $38,42 \mathrm{~mm}$ dan berdasarkan metode Beta $(\beta)$ daya dukung yang terendah pada titik BH 01 yaitu $Q_{u}=29,33$ ton dengan $Q_{a}=9,78$ ton dan penurunannya $38,42 \mathrm{~mm}$.
\end{abstract}

Kata kunci : Daya dukung tanah; Pondasi tiang pancang; Penurunan tiang tunggal.

\section{PENDAHULUAN}

Memasuki era globalisasi, dunia pendidikan di Indonesia terus berkembang. Sekolah Islam Al Azhar 57 Jambi yang berada dibawah naungan Yayasan Pesantren Islam Al Azhar Jakarta bekerjasama dengan Yayasan Muslim Jambi merupakan cabang yang ke 57 dari 185 sekolah Al Azhar yang tersebar di seluruh kota pada 18 Provinsi di Indonesia. Dengan tujuan untuk mewujudkan syiar pendidikan Islam yang bermutu di tanah air.

Salah satu aspek penting dalam perencanaan gedung Sekolah Islam Al Azhar 57 Jambi adalah kekuatan struktur dan jenis pondasi. Perhitungan kekuatan struktur pondasi salah satunya ditentukan oleh daya dukung tanah. Guna mengetahui kondisi daya dukung tanah telah dilakukan penyelidikan tanah menggunakan alat sondir atau Cone Penetration Test (CPT) sebanyak 6 titik oleh Laboratorium Fakultas Teknik Universitas Batanghari pada April 2018. Pada Oktober 2018 juga dilakukan pekerjaan Deep Boring sebanyak 4 titik serta pengujian SPT (Standard Penetration Test) sekaligus pengambilan sample tanah tak terganggu dan uji laboratorium terhadap sample tanah yang dikerjakan PT. Bahana Tehnik Raya.

Tujuan dari penelitian ini adalah untuk membandingkan hasil perhitungan kapasitas daya dukung pondasi dari data sondir, hasil uji SPT dan hasil uji laboratorium menggunakan beberapa metode serta menghitung penurunan tiang tunggal dengan variasi kedalaman. Sehingga diperoleh daya dukung pondasi tiang pancang yang paling aman.

Penggunaan pondasi tiang pancang sebagai pondasi bangunan apabila tanah yang berada dibawah dasar bangunan tidak mempunyai daya dukung (bearing capacity) yang cukup untuk memikul berat bangunan dan beban yang bekerja padanya (Sardjono H. S., 1988). 
Danipra Setiyo et al, Analisa Daya Dukung Tanah untuk Pondasi Tiang Pancang pada Rencana Pembangunan Komplek Pendidikan Islam Al Azhar 57 Jambi

Fungsi dan kegunaan dari pondasi tiang pancang adalah untuk memindahkan atau mentransfer bebanbeban dari konstruksi di atasnya (super struktur) ke lapisan tanah keras yang letaknya sangat dalam. Dalam pelaksanaan pemancangan pada umumnya dipancangkan tegak lurus dalam tanah, tetapi ada juga dipancangkan miring (battle pile) untuk dapat menahan gaya-gaya horizontal yang bekerja. Sudut kemiringan yang dapat dicapai oleh tiang tergantung dari alat yang dipergunakan serta disesuaikan pula dengan perencanaannya (J. E. Bowles, 1992).

Untuk mendistribusikan beban-beban dari konstruksi di atasnya dapat dilakukan dengan menggunakan gesekan antara tiang dan tanah (tiang pancang apung) maupun dengan tahanan ujung dari tiang tersebut. sehingga distribusi beban pada tiang pancang merupakan kombinasi dari tahanan samping (selimut tiang) dan tahanan ujung.

Daya dukung tanah $(Q)$ atau bearing capacity adalah kemampuan tanah memikul tekanan, atau tekanan maksimum yang diijinkan yang bekerja pada tanah di atas pondasi (A. Pamungkas dan E. Harianti, 2013).

Kapasitas dukung ultimit (ultimite bearing capacity) $\left(q_{u}\right)$ didefinisikan sebagai beban maksimum per satuan luas dimana tanah masih dapat mendukung beban tanpa mengalami keruntuhan (H. C. Hardiyatmo, 2011). Penentuan daya dukung pondasi tiang pancang dengan cara statis dilakukan dengan menggunakan beberapa formula berdasarkan hasil sondir atau Cone Penetration Test (CPT), hasil uji penetrasi lapangan dengan Standart Penetration Test (SPT), dan hasil uji laboratorium berupa parameter kuat geser tanah.

\section{Menghitungan kapasitas daya dukung pondasi tiang pancang}

\section{Menggunakan data Sondir}

Dari data pengujian sondir $(C P T)$ dapat dipergunakan untuk menghitung daya dukung pondasi tiang pancang dan diklasifikasikan atas beberapa formula diantaranya:

a. Metode Aoki dan De Alencar (1975)

Daya dukung ujung persatuan luas $\left(q_{b}\right)$ :

$q_{b}=\frac{q_{c a}(\text { base })}{F_{b}}$

Kapasitas dukung ujung tiang $\left(Q_{b}\right)$ :

$Q_{b}=q_{b} \times A_{p}$

Tahanan kulit persatuan luas $(F)$ :

$F=q_{c}($ side $) \frac{\alpha_{s}}{F_{s}}$

Kapasitas dukung kulit $\left(Q_{s}\right)$ :

$Q_{s}=F \mathrm{x} A_{s}$

Kapasitas dukung ultimit tiang $\left(Q_{u}\right)$ :

$Q_{u}=Q_{b}+Q_{s}$

Kapasitas ijin pondasi tiang $\left(Q_{a}\right)$ :

$Q_{a}=\frac{Q_{u}}{2,5}$

Dimana:

$q_{c a}($ base $)=$ Perlawanan konus rata-rata 1,5D diatas ujung tiang, 1,5D dibawah ujung tiang

$F_{b} \quad=$ Faktor empirik tahanan ujung tiang tergantung pada tipe tiang

$A_{p} \quad=$ Luas penampang tiang

$q_{c a}($ side $)=$ Perlawanan konus rata-rata pada masing-masing lapisan sepanjang tiang

$F_{s} \quad=$ Faktor empirik tahanan kulit tiang yang tergantung pada tipe tiang

Faktor $F_{b}$ dan $F_{s}$ diberikan pada Tabel 1. dan nilai-nilai faktor empirik $\alpha_{s}$ diberikan pada Tabel 2.

Tabel 1. Faktor empirik $F b$ dan $F s$

\begin{tabular}{ccc}
\hline Tipe tiang pancang & $\boldsymbol{F b}$ & $\boldsymbol{F} \boldsymbol{s}$ \\
\hline Tiang bor & 3,50 & 7,00 \\
Baja & 1,75 & 3,50 \\
Beton pratekan & 1,75 & 3,50 \\
\hline
\end{tabular}


Danipra Setiyo et al, Analisa Daya Dukung Tanah untuk Pondasi Tiang Pancang pada Rencana Pembangunan Komplek Pendidikan Islam Al Azhar 57 Jambi

Tabel 2. Nilai faktor empirik untuk tipe tanah

\begin{tabular}{|c|c|c|c|c|c|}
\hline Tipe tanah & $\alpha_{\mathrm{s}}(\%)$ & Tipe tanah & $\alpha_{\mathrm{s}}(\%)$ & Tipe tanah & $\alpha_{\mathrm{s}}(\%)$ \\
\hline Pasir & 1,4 & Pasir berlanau & 2,2 & Lempung berpasir & 2,4 \\
\hline Pasir kelanauan & 2,0 & Pasir berlanau dengan lempung & 2,8 & Lempung berpasir dengan lanau & 2,8 \\
\hline Pasir kelanauan dengan lempung & 2,4 & Lanau & 3,0 & Lempung berlanau dengan pasir & 3,0 \\
\hline Pasir berlempung dengan lanau & 2,8 & Lanau berlempung dengan pasir & 3,0 & Lempung berlanau & 4,0 \\
\hline Pasir berlempung & 3,0 & Lanau berlempung & 3,4 & Lempung & 6,0 \\
\hline
\end{tabular}

Sumber: Titi \& Farsakh, 1999

Pada umumnya nilai $\alpha_{s}$ untuk pasir $=1,4$ persen, nilai $\alpha_{s}$ untuk lanau $=3,0$ persen dan nilai $\alpha_{s}$ untuk lempung $=1,4$ persen. Perbandingan (rasio) antara tahanan gesek dan tahanan konus, Friction Ratio $\left(F_{R}\right)$ dapat digunakan untuk memprediksi jenis atau tipe tanah. seperti terlihat pada Gambar 1. [Robertson and Campanella (1983)].

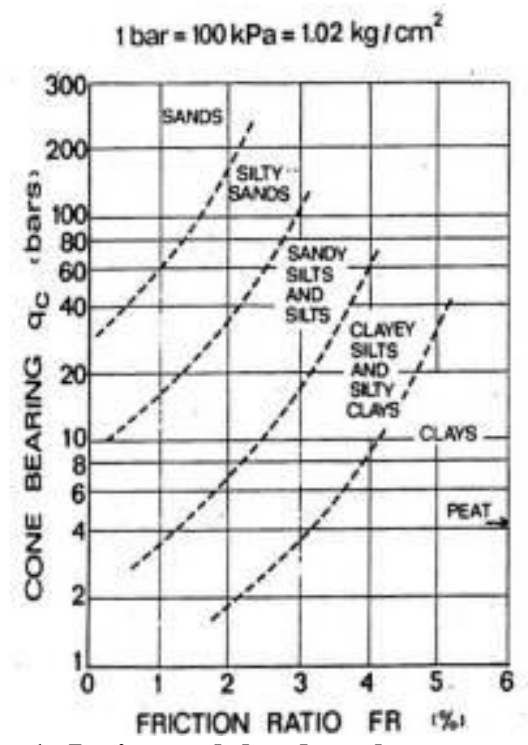

Gambar 1. Jenis tanah berdasarkan pengujian CPT

Sumber: Robertson and Campanella, 1983

b. Metode Langsung

Kapasitas daya dukung tiang pancang tunggal $\left(Q_{u}\right)$ :

$Q_{u}=q_{c} \times A_{p}+J H L \times p$

$\rightarrow Q_{b}=q_{c} \times A_{p}$

$\rightarrow Q_{s}=J H L x p$

Kapasitas ijin pondasi tiang $\left(Q_{a}\right)$ :

$Q_{a}=\frac{q_{c} \times A_{p}}{3}+\frac{J H L \times p}{5}$

Dimana:

$q_{c} \quad=$ Perlawanan penetrasi konus pada kedalaman yang ditinjau

Dapat digunakan faktor koreksi Meyerhoff:

$q_{c} 1 \quad=$ Rata-rata $q_{c} 8 \mathrm{D}$ diatas ujung tiang

$q_{c} 2=$ Rata-rata $q_{c} 4 \mathrm{D}$ diatas ujung tiang

$A_{p} \quad$ = Luas penampang tiang

$J H L=$ Jumlah hambatan lekat

$p \quad=$ Keliling tiang

$3=$ Faktor keamanan untuk daya dukung tiang

$5=$ Faktor keamanan untuk gesekan pada selimut tiang 
Danipra Setiyo et al, Analisa Daya Dukung Tanah untuk Pondasi Tiang Pancang pada Rencana Pembangunan Komplek Pendidikan Islam Al Azhar 57 Jambi

\section{Menggunakan data SPT}

Perhitungan kapasitas daya dukung pondasi tiang pancang per lapisan menggunakan data uji SPT dengan Metode Meyerhoff:

Daya dukung ujung tiang pada tanah kohesif plastis $\left(Q_{p}\right)$ :

$Q_{p}=9 . c_{u} . A_{p}$

$c_{u}=N-S P T .2 / 3.10$

Tahanan geser selimut tiang pada tanah kohesif plastis $\left(Q_{s}\right)$ :

$Q_{s}=\alpha \cdot c_{u} \cdot p \cdot L_{i}$

Kapasitas dukung ultimit tiang $\left(Q_{u}\right)$ :

$Q_{u l t}=Q_{p}+Q_{s}$

Kapasitas ijin pondasi tiang $\left(Q_{a}\right)$ :

$Q_{a}=\frac{Q_{p}}{3}+\frac{Q_{s}}{1,5}$

Dimana:

$c_{u} \quad=$ Kohesi Undrained

$A_{p} \quad$ = Luas penampang tiang

$\alpha \quad=$ Koefisien adhesi antara tanah dan tiang, yang diperoleh dari grafik korelasi $\alpha$ dan $c_{u}$ (didapat dari Gambar 2.)

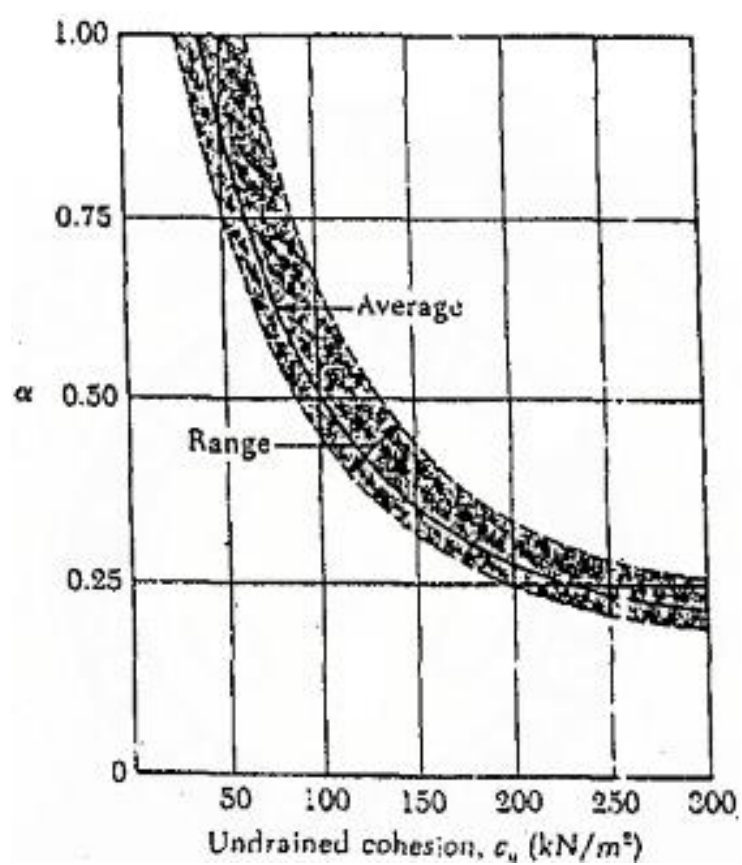

Gambar 2. Hubungan antara faktor Adhesi $(\alpha)$ dan kohesi Undrained $\left(c_{u}\right)$

Sumber: Meyerhoff, 1976

$p \quad=$ Keliling tiang

$L_{i} \quad=$ Panjang lapisan tanah

3 = Faktor keamanan untuk daya dukung tiang

1,5 = Faktor keamanan untuk gesekan pada selimut tiang

\section{Menggunakan data Uji Laboratorium}

Berdasarkan hasil pemeriksaan tanah melalui beberapa percobaan akan didapatkan nilai berat isi tanah $(\gamma)$, nilai kohesif tanah $(c)$ serta nilai sudut geser tanah $(\varphi)$. Kapasitas titik akhir dari sebuah tiang pancang dapat dihitung dengan menggunakan data uji laboratorium maupun data uji penetrasi. Jika data uji laboratorium (atau ekivalennya yang diambil dari pengujian penetrasi) digunakan, maka kapasitas maksimum tahanan ujung dapat dihitung sebagai berikut:

$P_{p u}=A_{p} \cdot\left(C \cdot N_{c}+\eta \cdot \bar{q} \cdot N_{q}\right)$

Dimana: 
Danipra Setiyo et al, Analisa Daya Dukung Tanah untuk Pondasi Tiang Pancang pada Rencana Pembangunan Komplek Pendidikan Islam Al Azhar 57 Jambi

$P_{p u} \quad=$ Kapasitas ultimit tahanan ujung tiang

$A_{p} \quad=$ Luas penampang tiang pancang

$C \quad=$ Kohesi tanah

$N_{c} \quad=$ Faktor kapasitas daya dukung, tergantung pada sudut geser tanah $(\varphi)$

$N_{q} \quad$ = Faktor kapasitas daya dukung, tergantung pada harga $\mathrm{L} / \mathrm{B}>1$ dan bergantung pada sudut geser tanah $(\varphi)$

$\bar{q} \quad=$ Tegangan vertikal efektif pada titik tiang pancang, $\bar{q}=\gamma \cdot Z$

$Z \quad$ = Kedalaman yang ditinjau

$\eta \quad=1$ untuk semua kecuali faktor-faktor Vesic (1975) dimana $\eta=\frac{1+2 K o}{3}$

$K_{0} \quad=$ Koefisien tanah dalam keadaan diam, $K_{0}=\left(1-\sin \phi^{\prime}\right) \sqrt{O C R}$

Faktor-faktor kapasitas daya dukung $\left(N_{c}\right.$ dan $\left.N_{q}\right)$ dapat ditentukan berdasarkan grafik daya dukung tanah sebagai berikut:

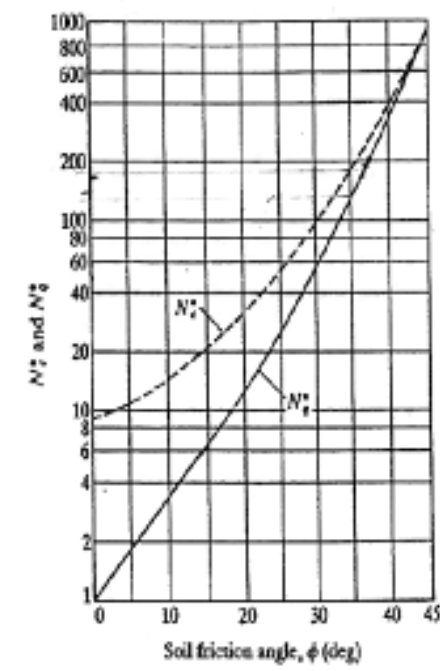

Gambar 3. Grafik daya dukung tanah Meyerhoff Sumber: Meyerhoff, 1976

Daya dukung gesekan (selimut tiang) atau tahanan kulit tiang dapat dihitung dengan beberapa formula diantaranya:

a. Metode $\alpha$

Metode $\alpha$ diusulkan oleh Tomlinson (1971) dan pada dasarnya tahanan kulit $\left(f_{s}\right)$ dihitung sebagai berikut:

$f_{s}=\alpha c+\bar{q} K \tan \delta$

Dimana:

$\alpha \quad=$ Koefisien dari Tabel 3.

$\mathrm{c} \quad=$ Kohesi rata-rata (atau $s_{u}$ ) untuk lapisan tanah yang diperlukan

$K=$ Koefisien tekanan tanah lateral pada tiang

$\delta \quad=$ Sudut gesekan efektif antara tanah dan bahan tiang pancang.

Tabel 3. Nilai-nilai Faktor Adhesi untuk Tiang Pancang yang dipancang ke dalam Tanah Kohesif Kaku (Stiff Cohesive Soil) dan Tanah Kohesif sangat Kaku untuk Perencanaan [Menurut Tomlinson (1971)]

\begin{tabular}{clcc}
\hline \multirow{2}{*}{ Kasus } & \multicolumn{1}{c}{ Kondisi tanah } & $\begin{array}{c}\text { Perbandingan } \\
\text { Penetrasi }\end{array}$ & $\begin{array}{c}\text { Faktor } \\
\text { Adhesi, } \alpha\end{array}$ \\
\hline \multirow{2}{*}{1} & $\begin{array}{l}\text { Pasir atau kerikil berpasir yang terletak di atas tanah kohesif mulai dari yang } \\
\text { kekuatan sampai dengan yang sangat kaku }\end{array}$ & $<20$ & $>20$ \\
2 & $\begin{array}{l}\text { Lempung lembek atas lumpur yang terletak di atas tanah kohesif mulai dari yang } \\
\text { keras sampai dengan yang sangat keras }\end{array}$ & $8<P R \leq 20$ & $>20$ \\
& $\begin{array}{l}\text { Tanah-tanah kohesif dari yang keras sampai dengan yang sangat keras tanpa } \\
\text { lapisan di atasnya }\end{array}$ & $8<P R \leq 20$ & 0,40 \\
\hline
\end{tabular}

Sumber: J. E. Bowles, 1992 
Danipra Setiyo et al, Analisa Daya Dukung Tanah untuk Pondasi Tiang Pancang pada Rencana Pembangunan Komplek Pendidikan Islam Al Azhar 57 Jambi

b. Metode $\lambda$

Vijay vergiya dan Focht (1972) memberikan suatu metode untuk mendapatkan tahanan kulit $\left(f_{s}\right)$ dari suatu tiang pancang di dalam lempung, sebagai berikut:

$f_{s}=\lambda\left(\bar{q}+2 s_{u}\right)$

Dimana:

$\lambda \quad=$ Koefisien lekatan terhadap kedalaman, dapat diperoleh dari Gambar 4.

$s_{u}=$ Kuat geser undrained dari tanah

c. Metode $\beta$

Metode ini diusulkan oleh Burland (1973) dan tahanan kulit $\left(f_{s}\right)$ dihitung sebagai berikut:

$f_{s}=K \bar{q} \tan \delta$

Dimana:

$\bar{q}, \delta=$ Harga-harga yang ditentukan dalam persamaan sebelumnya

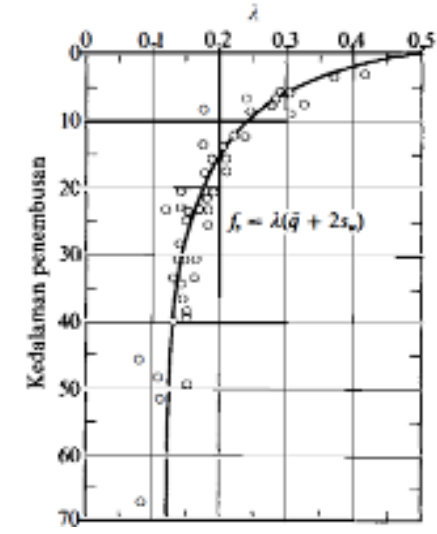

Gambar 4. Grafik hubungan harga $\lambda$ dengan kedalaman

Sumber: J. E. Bowles, 1992

Kapasitas dukung ultimit tiang $\left(Q_{u l t}\right)$ diperoleh dari daya dukung tahanan ujung $\left(P_{p u}\right)$ dijumlahkan dengan daya dukung gesekan (selimut tiang) atau tahanan kulit tiang $\left(P_{u}\right)$ yang dijelaskan dari persamaan berikut:

$Q_{u l t}=P_{p u}+P_{u}$

$P_{u}=\Sigma P_{s i}$

$P_{s i}=(\pi \mathrm{D} . \mathrm{Z}) \cdot f_{s}$

Dimana:

$\pi \quad=$ Konstanta: 3,14

$D=$ Diameter tiang pancang

$Z \quad=$ Kedalaman yang ditinjau

Kapasitas ijin pondasi tiang $\left(Q_{i j i n}\right)$ :

$Q_{i j i n}=\frac{\text { Qult }}{3}$

Dimana:

$3=$ Faktor keamanan untuk daya dukung tiang

\section{Penurunan Pondasi Tiang Tunggal}

Metode yang digunakan untuk perhitungan penurunan pondasi tiang tunggal yaitu metode Poulos dan Davis (1980).

1. Untuk tiang apung (flooting pile)

$$
\begin{aligned}
S & =\frac{Q I}{E_{s} d} \ldots \ldots \ldots . . . . . . \\
I & =I_{o} R_{k} R_{h} R_{\mu}
\end{aligned}
$$

Dimana: 
Danipra Setiyo et al, Analisa Daya Dukung Tanah untuk Pondasi Tiang Pancang pada Rencana Pembangunan Komplek Pendidikan Islam Al Azhar 57 Jambi

$S=$ Penurunan tiang

$Q=$ Beban yang bekerja

$I_{o}=$ Faktor pengaruh penurunan untuk tiang yang tidak mudah mampat (incompressible) dalam massa semi tak terhingga (Gambar 5.)

$R_{k}=$ Faktor koreksi kemudah-mampatan (kompresibilitas) tiang untuk $\mu=0,5$ (Gambar 6.)

$R_{h}=$ Faktor koreksi untuk ketebalan lapisan yang terletak pada tanah keras (Gambar 7.)

$R_{\mu}=$ Faktor koreksi angka Poisson $\mu$ (Gambar 8.)

$h=$ Kedalaman total lapisan tanah dari ujung tiang ke muka tanah

$E_{s}=$ Modulus elastisitas tanah disekitar tiang

$d=$ Diameter Tiang

Terlihat pada Gambar 5. bahwa penurunan tiang berkurang jika panjang tiang bertambah.

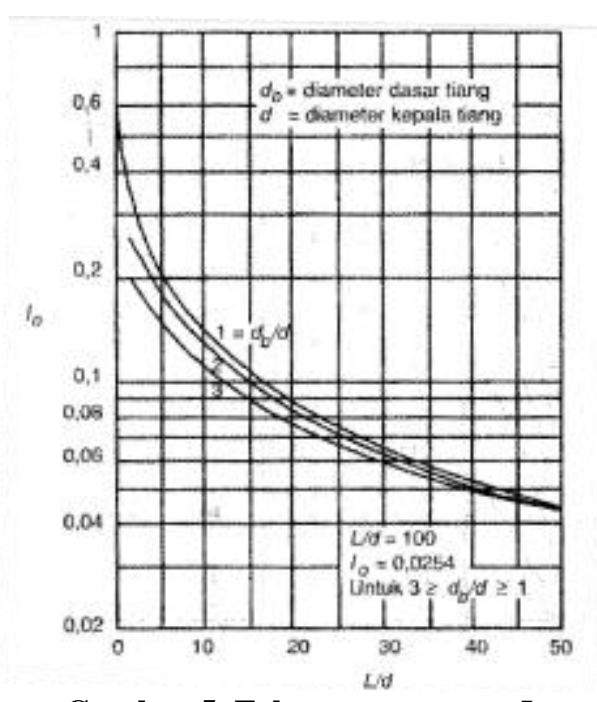

Gambar 5. Faktor penurunan $I_{o}$

Sumber: A. Pamungkas dan E. Harianti, 2013

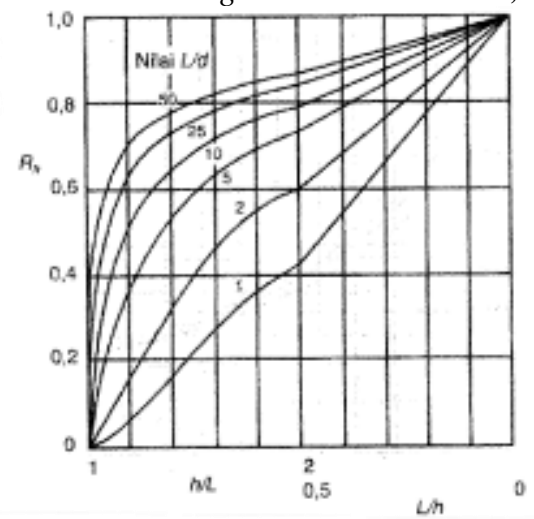

Gambar 7. Koreksi kedalaman, $\boldsymbol{R}_{\boldsymbol{h}}$

Sumber: A. Pamungkas dan E. Harianti, 2013

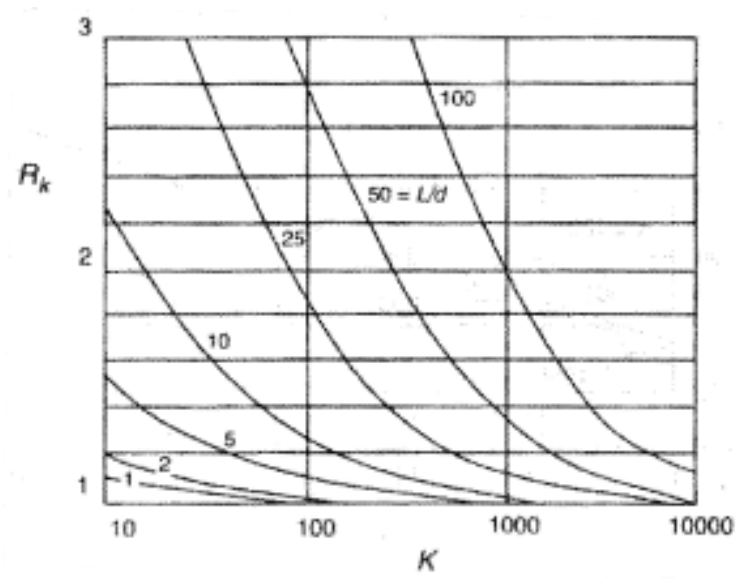

Gambar 6. Koreksi kompresi, $\boldsymbol{R}_{\boldsymbol{k}}$

Sumber: A. Pamungkas dan E. Harianti, 2013

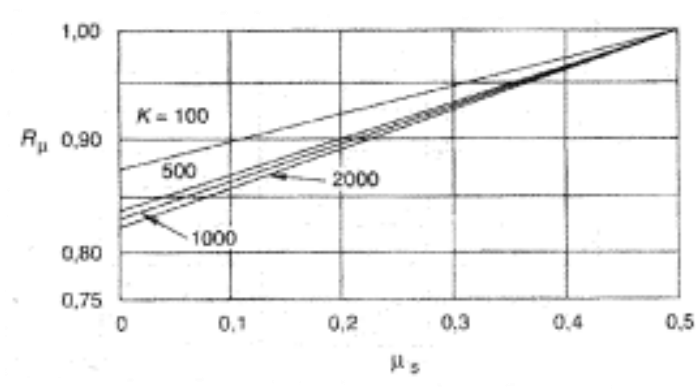

Gambar 8. Koreksi angka Poisson, $\boldsymbol{R}_{\boldsymbol{\mu}}$ Sumber: A. Pamungkas dan E. Harianti, 2013

2. Untuk tiang dukung ujung

$$
S=\frac{Q I}{E_{s} d}
$$

$I=I_{o} R_{k} R_{b} R_{\mu}$

Nilai-nilai koefisien dapat diambil dari Gambar 5. sampai 9. dengan $R_{b}=$ faktor koreksi untuk kekakuan lapisan pendukung (Gambar 9.). 

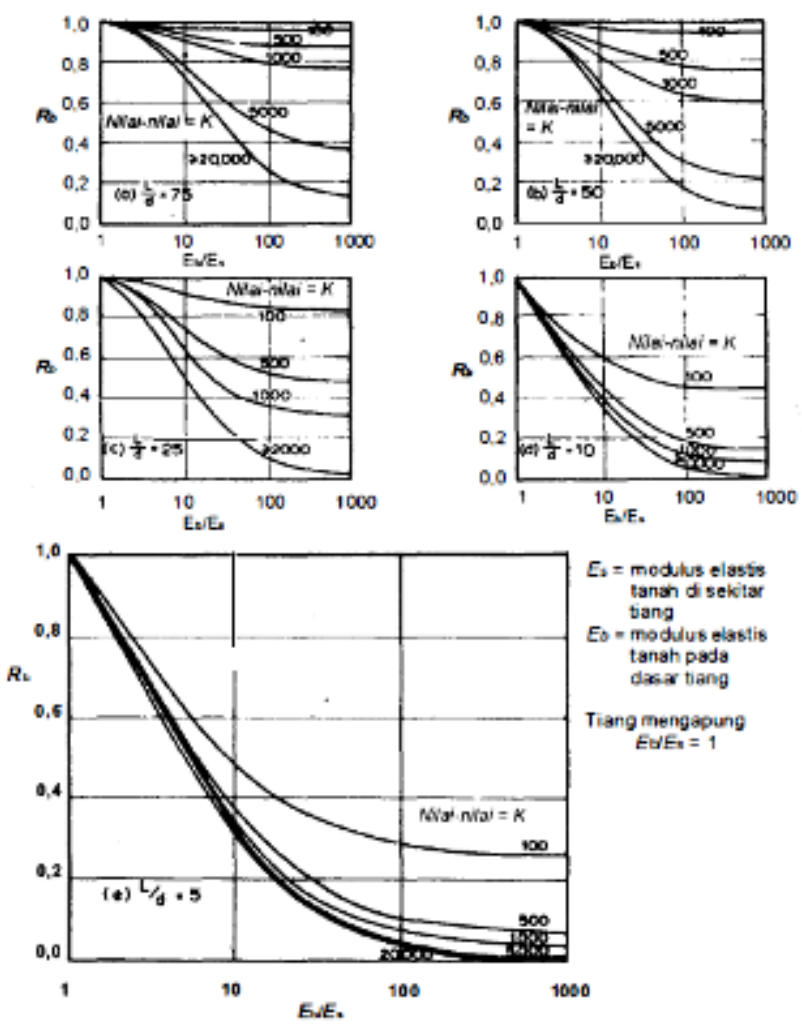

Gambar 9. Koreksi kekakuan lapisan pendukung, $\boldsymbol{R}_{b}$ Sumber: H. C. Hardiyatmo, 2008

Pengaruh kekerasan tanah pendukung di dasar tiang adalah mengurangi penurunan. Pengaruh ini menjadi lebih jelas bila tiang relatif pendek (tiang kaku) terletak pada lapisan pendukung yang keras. Pada Gambar 6., 8. dan 9., $K$ adalah suatu ukuran kompresibilitas relatif dari tiang dan tanah yang dinyatakan oleh persamaan:

$K=\frac{E_{p} R A}{E_{s}}=$ Faktor kekakuan tiang

$R_{A}=\frac{A_{p}}{1 / 4 \pi d^{2}}=$ Rasio area tiang

$E_{p}$ dan $E_{s}$ beturut-turut adalah modulus elastis bahan tiang dan tanah, $A_{p}$ adalah luas penampang tiang. Jika tiang makin kompresibel, maka $K$ semakin kecil.

Perkiraan angka Poisson $(\mu)$ dapat dilihat pada Tabel 2.7, Terzaghi menyarankan nilai $\mu=0,3$ untuk tanah pasir, dan $\mu=0,4$ sampai 0,43 untuk tanah lempung. Umumnya banyak digunakan $\mu=0,3$ sampai 0,35 untuk tanah pasir dan $\mu=0,4$ sampai 0,5 untuk tanah lempung.

Tabel 4. Perkiraan angka Poisson $(\mu)$

\begin{tabular}{cc}
\hline Macam tanah & $\boldsymbol{\mu}$ \\
\hline Lempung jenuh & $0,4-0,5$ \\
Lempung tak jenuh & $0,1-0,3$ \\
Lempung berpasir & $0,2-0,3$ \\
Lanau & $0,3-0,35$ \\
Pasir padat & $0,2-0,4$ \\
Pasir kasar & 0,15 \\
Pasir halus & 0,25 \\
Batu (tergantung dari tipenya) & $0,1-0,4$ \\
Loess & $0,1-0,3$ \\
\hline
\end{tabular}


Untuk menentukan nilai modulus elastisitas tanah $\left(E_{s}\right)$, Bowles (1977), memberikan persamaan yang dihasilkan dari pengumpulan data pengujian kerucut statis (sondir), sebagai berikut:
$E_{s}=3 q_{c}$
(untuk pasir).
$E_{s}=2$ sampai $8 q_{c} \quad$ (untuk lempung)...(28b)

dengan $q_{c}$ dalam $\mathrm{kg} / \mathrm{cm}^{2}$

3. Penurunan yang diizinkan

Syarat perbandingan penurunan yang aman disajikan pada persamaan (29) (Parinduri dan Iskandar, 2014).

$S_{\text {total }} \leq S_{\text {izin }}$

$S_{i z i n}=10 \% \cdot D$

Dimana:

$D=$ Diameter tiang

\section{METODE PENELITIAN}

\section{Data Umum}

Rencana Pembangunan Komplek Pendidikan Islam Al Azhar 57 Jambi berada di kawasan kota baru terpadu Citra Raya City, Desa Mendalo Darat, Kecamatan Jambi Luar Kota, Kabupaten Muaro Jambi Provinsi Jambi.

\section{Data Teknis}

Data dalam penelitian ini merupakan data sekunder, yaitu data tanah dan spesifikasi tiang pancang yang diperoleh dari pihak PT. A\&Art Partner selaku kontraktor. Adapun detail data tanah yang diperoleh sebagai berikut:

1. Data hasil uji sondir atau Cone Penetration Test (CPT) yang dikerjakan oleh Laboratorium Fakultas Teknik Universitas Batanghari.

2. Data hasil uji penetrasi standar (SPT) dan hasil uji laboratorium yang dikerjakan oleh PT. Bahana Tehnik Raya.

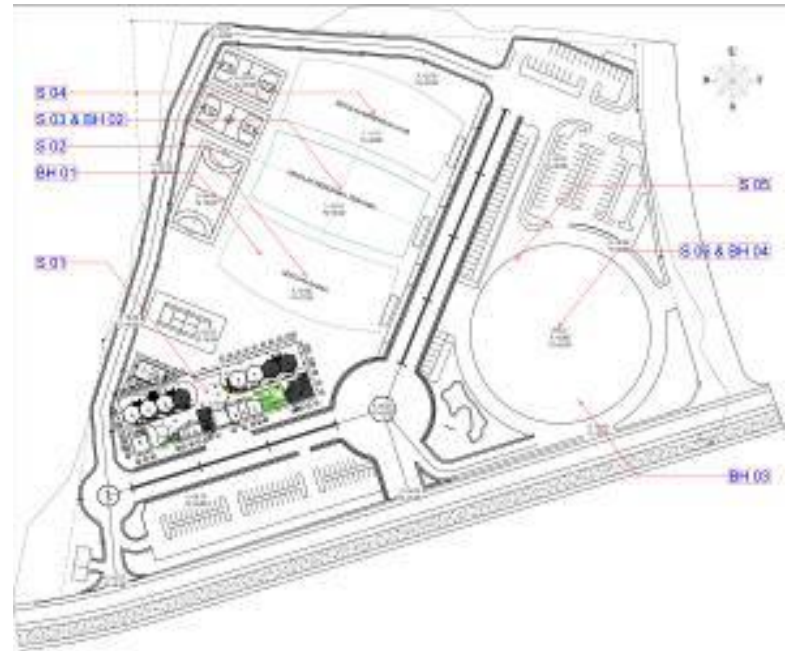

\section{Gambar 10. Layout Pengambilan Sample} Sumber: PT. A\&Art Partner, 2019

Sedangkan detail spesifikasi tiang pancang yang diperoleh sebagai berikut:

1. Material tiang pancang : Tiang beton pracetak (precast pile)

2. Penampang tiang : Segi empat $450 \times 450 \mathrm{~mm}$

3. Mutu Pc Strand/Pc Wire : ASTM Grade 270, JIS G 3536

4. Mutu Beton : K-350

5. Mutu Baja : BJTD-40/U-39

Langkah-langkah yang dilakukan dalam penelitian ini seperti yang ditunjukkan pada Gambar 11. berikut ini. 


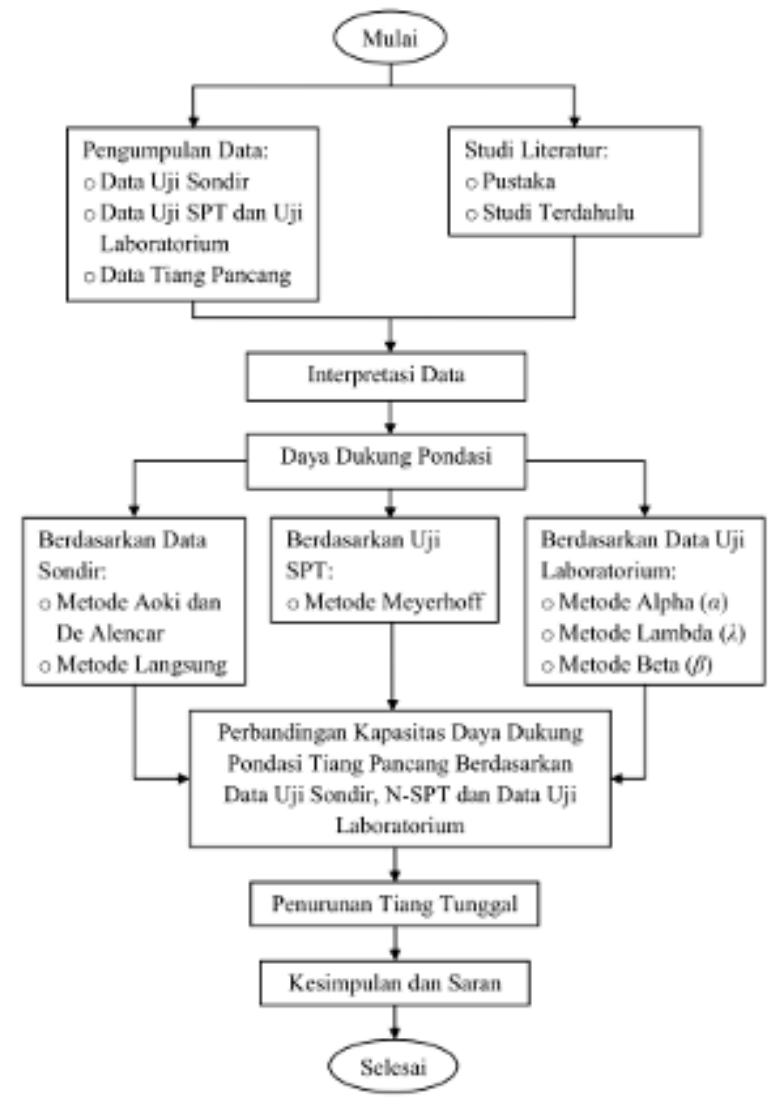

Gambar 11. Diagram alir pelaksanaan penelitian Sumber: PT. A\&Art Partner, 2019

\section{HASIL DAN PEMBAHASAN}

Perhitungan daya dukung pondasi tiang pancang berdasarkan data hasil sondir

Berikut disajikan rekapitulasi data hasil uji sondir dalam Tabel 5.

Tabel 5. Rekapitulasi Hasil Sondir

\begin{tabular}{|c|c|c|c|c|}
\hline No. Titik & $Q c\left(\mathrm{~kg} / \mathrm{cm}^{2}\right)$ & JHL (kg/cm) & Kedalaman (m) & Muka Air Tanah (m) \\
\hline S 01 & 150 & 1642 & $-10,8$ & -- \\
\hline S 02 & 150 & 2808 & $-12,6$ & -- \\
\hline S 03 & 150 & 2168 & $-12,8$ & -- \\
\hline S 04 & 150 & 1946 & $-12,2$ & -- \\
\hline S 05 & 150 & 2478 & $-12,2$ & -- \\
\hline S 06 & 150 & 3204 & $-13,6$ & -- \\
\hline
\end{tabular}

Sumber: Laboratorium F.T. Universitas Batanghari, 2018

Daya dukung pondasi tiang pancang dihitung menggunakan Metode Aoki dan De Alencar dan Metode Langsung.

Tabel 6. Rekapitulasi Hasil Perhitungan Daya Dukung Pondasi dengan Metode Aoki dan De Alencar

\begin{tabular}{|c|c|c|c|c|c|c|c|c|}
\hline \multicolumn{3}{|c|}{ Titik } & \multicolumn{6}{|c|}{ Kedalaman (m) } \\
\hline & & & 5 & 6 & 7 & 8 & 9 & 10 \\
\hline \multirow{2}{*}{ S 01} & \multirow{8}{*}{ 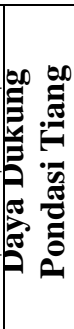 } & $Q_{u}$ & 59,91 & 69,71 & 92,11 & 155,98 & 161,43 & 227,57 \\
\hline & & $Q_{a}$ & 23,97 & 27,88 & 36,84 & 62,39 & 64,57 & 91,03 \\
\hline \multirow{4}{*}{$\begin{array}{l}\text { S } 02 \\
\text { S } 03\end{array}$} & & $Q_{u}$ & 51,30 & 73,03 & 90,64 & 110,55 & 125,10 & 175,20 \\
\hline & & $Q_{a}$ & 20,52 & 29,21 & 36,26 & 44,22 & 50,04 & 70,08 \\
\hline & & $Q_{u}$ & 86,96 & 101,94 & 123,47 & 151,65 & 169,96 & 182,49 \\
\hline & & $Q_{a}$ & 34,78 & 40,77 & 49,39 & 60,66 & 67,98 & 73,00 \\
\hline \multirow{2}{*}{ S 04} & & $Q_{u}$ & 80,36 & 92,31 & 104,76 & 123,04 & 146,31 & 174,21 \\
\hline & & $Q_{a}$ & 32,14 & 36,93 & 41,90 & 49,22 & 58,53 & 69,69 \\
\hline
\end{tabular}


Danipra Setiyo et al, Analisa Daya Dukung Tanah untuk Pondasi Tiang Pancang pada Rencana Pembangunan Komplek Pendidikan Islam Al Azhar 57 Jambi

\begin{tabular}{|c|c|c|c|c|c|c|c|}
\hline \multirow{2}{*}{ S 05} & $Q_{u}$ & 7,82 & 13,15 & 30,75 & 71,78 & 88,79 & 97,44 \\
\hline & $Q_{a}$ & 3,13 & 5,26 & 12,30 & 28,71 & 35,52 & 38,98 \\
\hline \multirow{2}{*}{ S 06} & $Q_{u}$ & 15,69 & 29,56 & 61,29 & 65,44 & 88,89 & 88,84 \\
\hline & $Q_{a}$ & 6,27 & 11,82 & 24,51 & 26,18 & 35,56 & 35,54 \\
\hline
\end{tabular}

Tabel 7. Rekapitulasi Hasil Perhitungan Daya Dukung Pondasi Tiang Pancang dengan Metode Langsung (Ton)

\begin{tabular}{|c|c|c|c|c|c|c|c|c|}
\hline \multirow{2}{*}{\multicolumn{3}{|c|}{ Titik }} & \multicolumn{6}{|c|}{ Kedalaman (m) } \\
\hline & & & \multirow{2}{*}{\begin{tabular}{|c|}
$\mathbf{5}$ \\
181,12
\end{tabular}} & \multirow{2}{*}{$\begin{array}{c}\mathbf{6} \\
220,26\end{array}$} & \multirow{2}{*}{$\begin{array}{c}7 \\
269,54\end{array}$} & \multirow{2}{*}{$\begin{array}{c}\mathbf{8} \\
326,73\end{array}$} & \multirow{2}{*}{$\frac{9}{393,29}$} & \multirow{2}{*}{$\begin{array}{c}\mathbf{1 0} \\
457,71\end{array}$} \\
\hline & \multirow{12}{*}{ 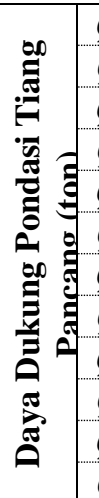 } & $Q_{u}$ & & & & & & \\
\hline S 01 & & $Q_{a}$ & 44,82 & 55,23 & 68,05 & 82,46 & 100,81 & 118,44 \\
\hline & & $Q_{u}$ & 301,84 & 336,06 & 384,55 & 422,86 & 460,54 & 540,04 \\
\hline S & & $Q_{a}$ & 69,41 & 77,70 & 89,83 & 99,14 & 109,06 & 126,93 \\
\hline & & $\widetilde{Q_{u}}$ & 292,64 & 345,17 & 401,31 & 438,86 & 474,64 & 7,70 \\
\hline & & $Q_{a}$ & 70,91 & 84,19 & 98,78 & 108,56 & 118,23 & 126,85 \\
\hline & & $Q_{u}$ & 236,62 & 275,66 & 309,53 & 343,21 & 380 & 432,49 \\
\hline & & $Q_{a}$ & 58,81 & 68,61 & 77,11 & 85,51 & 95,18 & 109,17 \\
\hline & & $Q_{u}$ & 152,25 & 187,86 & 241,48 & 288,07 & 322,09 & 365,34 \\
\hline & & $Q_{a}$ & 32,17 & 40,30 & 53,28 & 64,97 & 73,91 & 84,87 \\
\hline \multirow{2}{*}{ S 06} & & $Q_{u}$ & 188,42 & 227,24 & 270,23 & 322,28 & 377,01 & 442,48 \\
\hline & & $Q_{a}$ & 40,73 & 49,49 & 59,36 & 71,23 & 83,00 & 97,86 \\
\hline
\end{tabular}

Perhitungan kapasitas daya dukung pondasi tiang pancang berdasarkan data hasil SPT Pada titik BH 01, BH 02, BH 03 dan BH 04.

Tabel 8. Rekapitulasi Hasil Perhitungan Daya Dukung Pondasi Tiang Pancang dengan Metode Meyerhoff

\begin{tabular}{|c|c|c|c|c|c|c|c|c|}
\hline \multirow{3}{*}{ Depth (m) } & \multicolumn{8}{|c|}{ Daya Dukung Pondasi Tiang Pancang (ton) } \\
\hline & \multicolumn{2}{|c|}{ BH 01} & \multicolumn{2}{|c|}{ BH 02} & \multicolumn{2}{|c|}{ BH 03} & \multicolumn{2}{|c|}{ BH 04} \\
\hline & $Q_{u}$ & $Q_{a}$ & $Q_{u}$ & $Q_{a}$ & $Q_{u}$ & $Q_{a}$ & $Q_{u}$ & $Q_{a}$ \\
\hline 0,0 & - & - & - & - & - & - & - & - \\
\hline 2,0 & 21,69 & 12,03 & 14,46 & 8,02 & 14,46 & 8,02 & 24,30 & 13,36 \\
\hline 4,0 & 32,48 & 19,63 & 31,29 & 18,43 & 20,45 & 12,42 & 33,87 & 20,55 \\
\hline 6,0 & 48,09 & 29,63 & 34,85 & 22,02 & 38,49 & 23,23 & 55,58 & 33,41 \\
\hline 8,0 & 62,49 & 39,23 & 42,05 & 26,82 & 63,64 & 37,56 & 77,08 & 46,52 \\
\hline 10,0 & 81,05 & 50,79 & 62,70 & 38,96 & 74,90 & 46,70 & 92,17 & 57,39 \\
\hline
\end{tabular}

\section{Perhitungan kapasitas daya dukung pondasi tiang pancang berdasarkan data hasil Uji Laboratorium}

Perhitungan kapasitas dukung pondasi tiang pancang dengan menggunakan data hasil uji laboratorium terhadap sampel tanah tak terganggu UDS1, UDS2 dan UDS3 pada tiap-tiap titik BH 01, BH 02, BH 03 dan BH 04.

Tabel 9. Rekapitulasi Hasil Perhitungan Daya Dukung Pondasi Tiang Pancang dengan Metode Alpha ( $\alpha)$

\begin{tabular}{r|c|c|c|c|c|c|c|c}
\hline \multirow{3}{*}{ Depth (m) } & \multicolumn{8}{|c}{ Daya Dukung Pondasi Tiang Pancang (ton) } \\
\cline { 2 - 10 } & \multicolumn{2}{|c|}{$\mathbf{B H} 01$} & \multicolumn{2}{c}{$\mathbf{B H} 02$} & \multicolumn{2}{c}{ BH 03 } & \multicolumn{2}{c}{ BH 04 } \\
\hline & $\boldsymbol{Q}_{\boldsymbol{u}}$ & $\boldsymbol{Q}_{\boldsymbol{a}}$ & $\boldsymbol{Q}_{\boldsymbol{u}}$ & $\boldsymbol{Q}_{\boldsymbol{a}}$ & $\boldsymbol{Q}_{\boldsymbol{u}}$ & $\boldsymbol{Q}_{\boldsymbol{a}}$ & $\boldsymbol{Q}_{\boldsymbol{u}}$ & $\boldsymbol{Q}_{\boldsymbol{a}}$ \\
\hline 5,0 & 42,96 & 14,32 & 52,50 & 17,50 & 56,24 & 18,75 & 49,84 & 16,61 \\
6,0 & 51,92 & 17,31 & 62,44 & 20,81 & 67,22 & 22,41 & 59,56 & 19,85 \\
7,0 & 61,18 & 20,39 & 63,05 & 21,02 & 78,54 & 26,18 & 66,60 & 22,20 \\
8,0 & 70,75 & 23,58 & 72,44 & 24,15 & 90,22 & 30,07 & 77,99 & 26,00 \\
9,0 & 80,62 & 26,87 & 82,14 & 27,38 & 102,25 & 34,08 & 88,14 & 29,38 \\
10,0 & 83,38 & 27,79 & 92,15 & 30,72 & 114,54 & 38,18 & 98,40 & 32,80 \\
\hline \multicolumn{8}{c}{ Sumber: Analisis Data, diolah 2019 }
\end{tabular}


Danipra Setiyo et al, Analisa Daya Dukung Tanah untuk Pondasi Tiang Pancang pada Rencana Pembangunan Komplek Pendidikan Islam Al Azhar 57 Jambi

Tabel 10. Rekapitulasi Hasil Perhitungan Daya Dukung Pondasi Tiang Pancang dengan Metode Lambda ( $\lambda$ )

\begin{tabular}{|c|c|c|c|c|c|c|c|c|}
\hline \multirow{3}{*}{ Depth (m) } & \multicolumn{8}{|c|}{ Daya Dukung Pondasi Tiang Pancang (ton) } \\
\hline & \multicolumn{2}{|c|}{ BH 01} & \multicolumn{2}{|c|}{ BH 02} & \multicolumn{2}{|c|}{ BH 03} & \multicolumn{2}{|c|}{ BH 04} \\
\hline & $Q_{u}$ & $Q_{a}$ & $Q_{u}$ & $Q_{a}$ & $Q_{u}$ & $Q_{a}$ & $Q_{u}$ & $Q_{a}$ \\
\hline 5,0 & 38,53 & 12,84 & 49,44 & 16,48 & 48,21 & 16,07 & 46,05 & 15,35 \\
\hline 6,0 & 46,30 & 15,43 & 57,87 & 19,29 & 57,07 & 19,02 & 54,05 & 18,02 \\
\hline 7,0 & 54,73 & 18,24 & 57,71 & 19,24 & 66,61 & 22,20 & 57,22 & 19,07 \\
\hline 8,0 & 62,36 & 20,79 & 65,28 & 21,76 & 75,25 & 25,08 & 63,82 & 21,27 \\
\hline 9,0 & 70,54 & 23,51 & 73,37 & 24,46 & 84,44 & 28,15 & 69,29 & 23,10 \\
\hline 10,0 & 71,10 & 23,70 & 81,98 & 27,33 & 94,04 & 31,35 & 74,96 & 24,99 \\
\hline
\end{tabular}

Tabel 11. Rekap Hasil Perhitungan Daya Dukung Pondasi Tiang Pancang dengan Metode Beta $(\beta)$

\begin{tabular}{|c|c|c|c|c|c|c|c|c|}
\hline \multirow{3}{*}{ Depth (m) } & \multicolumn{8}{|c|}{ Daya Dukung Pondasi Tiang Pancang (ton) } \\
\hline & \multicolumn{2}{|c|}{ BH 01} & \multicolumn{2}{|c|}{ BH 02} & \multicolumn{2}{|c|}{ BH 03} & \multicolumn{2}{|c|}{ ВH 04} \\
\hline & $Q_{u}$ & $Q_{a}$ & $Q_{u}$ & $Q_{a}$ & $Q_{u}$ & $Q_{a}$ & $Q_{u}$ & $Q_{a}$ \\
\hline 5,0 & 18,93 & 6,31 & 31,30 & 10,43 & 30,10 & 10,03 & 25,82 & 8,61 \\
\hline 6,0 & 21,89 & 7,30 & 35,94 & 11,98 & 34,01 & 11,34 & 29,54 & 9,85 \\
\hline 7,0 & 25,15 & 8,38 & 31,08 & 10,36 & 38,27 & 12,76 & 27,92 & 9,31 \\
\hline 8,0 & 28,71 & 9,57 & 35,00 & 11,67 & 42,89 & 14,30 & 30,66 & 10,22 \\
\hline 9,0 & 32,58 & 10,86 & 39,22 & 13,07 & 47,85 & 15,95 & 32,15 & 10,72 \\
\hline 10,0 & 29,33 & 9,78 & 43,75 & 14,58 & 53,07 & 17,69 & 33,76 & 11,25 \\
\hline
\end{tabular}

Hasil perhitungan kapasitas daya dukung di atas adalah nilai ultimit. Daya dukung ijin pondasi tiang pancang yang dianggap rendah dari beberapa metode tersebut dibandingkan dalam Tabel 12 .

Tabel 12. Rekapitulasi Hasil Terkecil (Terendah) Perhitungan Daya Dukung Ijin Tiang Pancang (Ton)

\begin{tabular}{|c|c|c|c|c|c|c|}
\hline \multirow{4}{*}{ Kedalaman (m) } & \multicolumn{6}{|c|}{ METODE } \\
\hline & \multicolumn{2}{|c|}{ Uji Sondir (CPT) } & \multirow{2}{*}{$\begin{array}{c}\text { Uji SPT } \\
\text { Meyerhoff }\end{array}$} & \multicolumn{3}{|c|}{ Uji Laboratorium } \\
\hline & Aoki dan De Alencar & Langsung & & Alpha $(\alpha)$ & Lambda $(\lambda)$ & Beta $(\beta)$ \\
\hline & S 06 & S 05 & BH 02 & BH 01 & ВH 01 & BH 01 \\
\hline 5,0 & 6,27 & 32,17 & & 14,32 & 12,84 & 6,31 \\
\hline 6,0 & 11,82 & 40,30 & 22,02 & 17,31 & 15,43 & 7,30 \\
\hline 7,0 & 24,51 & 53,28 & & 20,39 & 18,24 & 8,38 \\
\hline 8,0 & 26,18 & 64,97 & 26,82 & 23,58 & 20,79 & 9,57 \\
\hline 9,0 & 35,56 & 73,91 & & 26,87 & 23,51 & 10,86 \\
\hline 10,0 & 35,54 & 84,87 & 38,96 & 27,79 & 23,70 & 9,78 \\
\hline
\end{tabular}

\section{Perhitungan penurunan tiang tunggal (single pile) dan penurunan yang diizinkan}

Perhitungan penurunan tiang tunggal pada tiap-tiap titik S 01, S 02, S 03, S 04, S 05, S 06, BH 01, BH 02, BH 03 dan $\mathrm{BH} 04$ dengan beberapa variasi kedalaman. Adapun metode yang digunakan yaitu metode Poulos dan Davis (1980).

Material tiang pancang yaitu tiang beton pracetak (precast pile) Segi empat 450 x $450 \mathrm{~mm}$ dengan mutu beton K-350.

Dari persamaan (29), Penurunan yang diizinkan $\left(S_{i z i n}\right)$ :

$S_{i z i n}=10 \% . D$

$S_{i z i n}=10 \% .45$

$S_{i z i n}=4,5 \mathrm{~cm}=45 \mathrm{~mm}$

Hasil perhitungan penurunan tiang tunggal dengan variasi kedalaman ditampilkan pada Tabel 13. 
Danipra Setiyo et al, Analisa Daya Dukung Tanah untuk Pondasi Tiang Pancang pada Rencana Pembangunan Komplek

Tabel 13. Perhitungan penurunan total tiang tunggal

\begin{tabular}{ccc}
\hline Titik & Depth $(\mathbf{m})$ & $\boldsymbol{S}_{\text {total }}(\mathbf{m m})$ \\
\hline S 01 & 10,8 & 26,56 \\
S 02 & 12,6 & 27,74 \\
S 03 & 12,8 & 22,17 \\
S 04 & 12,2 & 25,37 \\
S 05 & 12,2 & 44,26 \\
S 06 & 13,6 & 33,08 \\
BH 01 & 30,0 & 23,83 \\
BH 02 & 45,0 & 19,11 \\
BH 03 & 30,0 & 26,77 \\
BH 04 & 30,0 & 20,78 \\
BH 01 & 16,0 & 38,42 \\
BH 02 & 18,0 & 28,54 \\
BH 03 & 16,0 & 44,73 \\
BH 04 & 18,0 & 31,42 \\
\hline
\end{tabular}

Sumber: Analisis Data, diolah 2019

\section{SIMPULAN}

1. Dari hasil perhitungan kapasitas daya dukung pondasi tiang pancang berdasarkan data uji sondir di titik $S$ 01, S 02, S 03, S 04, S 05 dan S 06 menggunakan Metode Aoki dan De Alencar memiliki nilai daya dukung pondasi yang kecil sedangkan Metode Langsung memiliki nilai daya dukung pondasi yang besar.

2. Dari hasil perhitungan berdasarkan data uji SPT di titik BH 01, BH 02, BH 03 dan BH 04 menggunakan Metode Meyerhoff nilai daya dukung pondasinya lebih kecil dibandingkan dengan perhitungan berdasarkan data sondir.

3. Dari hasil perhitungan berdasarkan data hasil uji laboratorium terhadap sampel tanah tak terganggu UDS1, UDS2 dan UDS3 pada tiap-tiap titik BH 01, BH 02, BH 03 dan $\mathrm{BH}$ 04, dengan menggunakan Metode Alpha $(\alpha)$ memiliki nilai daya dukung pondasi yang besar dibandingkan dengan Metode Lambda $(\lambda)$ dan Metode Beta $(\beta)$, sedangkan menggunakan Metode Lambda $(\lambda)$ memiliki nilai daya dukung pondasi yang kecil dibandingkan Metode Alpha $(\alpha)$ namun lebih besar jika dibandingkan dengan Metode $\operatorname{Beta}(\beta)$.

4. Berdasarkan hasil perhitungan penurunan tiang tunggal dengan variasi kedalaman, untuk penurunan total tiang tunggal yang terjadi di tiap titik yang ditinjau seperti pada tabel 15. nilainya lebih kecil dari penurunan izin $45 \mathrm{~mm}$, maka penurunan total tiang tunggal memenuhi syarat perbandingan penurunan yang aman.

\section{DAFTAR PUSTAKA}

Bowles, J. E., 1992, Analisis dan Desain Pondasi, Edisi keempat Jilid 1 dan 2, Erlangga, Jakarta.

Das, M. B., 2011, Principles of Foundation Engineering, SI, Seventh Edition, Global Engineering, USA.

Hardiyatmo, H. C., 1996, Teknik Fondasi 1 dan 2, Edisi keempat, Gramedia Pustaka Utama, Jakarta.

Hardiyatmo, H. C., 2011, Analisis dan Perancangan Fondasi I, Gadjah Mada University Press, Yogyakarta.

Pamungkas, A. dan Harianty, E., 2013, Desain Pondasi Tahan Gempa, Andi Offset, Yogyakarta.

Parinduri, I. P. dan Iskandar, R., 2014, Analisis daya dukung pondasi dan penurunan tiang pancang pada proyek pengembangan gedung pendidikan dan prasarana serta sarana pendukung Politeknik Negeri Medan, Jurnal Teknik Sipil, Medan.

Sardjono, H. S., 1988, Pondasi Tiang Pancang, Jilid 1 dan 2, Sinar Wijaya, Surabaya.

Standar Nasional Indonesia, 2008, SNI 2827:2008 Cara Uji Penetrasi Lapangan Dengan Alat Sondir, Badan Standardisasi Nasional, Bandung.

Standar Nasional Indonesia, 2008, SNI 4153:2008 Cara Uji Penetrasi Lapangan Dengan SPT, Badan Standardisasi Nasional, Bandung.

Titi, H. H. and Farsakh, M. Y. A., 1999, Evalution of Bearing Capacity of Piles from Cone Penetration Test Data, Lousiana Transportation Research Center, LA. 